\title{
Assessment of Students Attitude and Perception of Teaching Practice: The Case of Undergraduates of Delta State University, Abraka
}

\author{
Asiyai Romina Ifeoma, ${ }^{1, *}$ \\ ${ }^{1}$ Department of Educational Administration and Policy Studies, Faculty of Education, Delta State University Abraka, \\ Nigeria \\ *Correspondence: Department of Educational Administration and Policy Studies, Faculty of Education, Delta State \\ University Abraka, Nigeria. E-mail: asiyairomina@yahoo.com
}

Received: October 23, 2015

Accepted: March 3, 2016 Online Published: April 19, 2016

doi:10.5430/wje.v6n2p82

URL: http://dx.doi.org/10.5430/wje.v6n2p82

\begin{abstract}
This descriptive survey research employed ex-post facto design to examine teaching practice in Delta State University, Abraka Nigeria. Interview and questionnaire were used to generate data from 280 respondents. Three research questions and three hypotheses guided the investigation. Data collected were analyzed via the use of mean, standard deviation and percent to answer the research questions and t-test to test the hypotheses, the level of significant was set at 0.05 . Findings revealed that student teachers have positive attitude towards teaching practice. This was reflected in their interest in the programme, regular attendance at school and writing of daily lesson notes. Additionally, the student teachers expressed that they had good relationship with their mentors. Findings on supervision provided by lecturers showed that rural school teachers were dissatisfied with their supervision, as some of them were not supervised. The study concluded by recommending among others that Delta State University should ensure that they post student teachers to schools with good access roads for ease of supervision by Lecturers.
\end{abstract}

Keywords: attitude; mentors; student teachers; supervisors; teaching practice

\section{Introduction}

Teachers occupy a very significant position in any education system. They are major determinants of the success or failure of any school. Whatever learning outcomes students attain depend on what goes on in the classroom between teachers and students. In addition, teachers are critical to human capital development and are the most significant contributors in the overall development of a nation. Buttressing the importance of teachers to national development, Ukeje cited in Nwanekezi, Okoli and Mezieobi (2011), Okemakinde, Adewuyi and Alabi (2013) emphasized that education unlocks the door to modernization and sustainable development but that it is teachers that hold the key to the door. This assertion could be because it is teachers that are responsible for translating educational policies into practice and programmes into action. The Nigerian national policy on education emphasized the importance of teachers by saying that "no educational system can rise above the quality of its teachers". In the Nigerian national policy on education, FGN (2004: 24, and Jekayinfa, Yahaya and Yusuf, et al (2012:80) the faculty of education in Nigerian universities is mandated with the responsibilities outlined as follows:

- Production of highly motivated, conscientious and effective classroom teachers for all level of Nigerian education system

- Help teachers to fit into the social life of the community at large and enhance their commitment to national objectives

- Encourage further the spirit of creativity and enquiry in teachers

- Provide teachers with intellectual and professional background adequate for their assignment and to make them adaptable to changing situations not only in life of their country but in the wider world

- Enhance teachers' commitment to the teaching profession.

Consequently, minimum academic standard was established in all faculties of education of Nigerian universities to facilitate the achievement of these laudable objectives. It is clear that no country can make meaningful step to 
national development without professionally trained teachers who are the key to quality teaching and learning. Teachers in Nigeria and many other countries of the world are trained at the faculty of education of universities and at the colleges of education, majority of which are affiliated to faculties of education of universities.

Teaching practice is an integral component of teacher education programme (Ekundayo, Alonge, Kolawole \& Ekundayo, 2014; Oluwatayo; Adebule, 2012, Mudzielwana \& Maphosa, 2014)). It is a basic requirement for all students of the faculty of education in 300 and 400 levels, each lasting for a period of six weeks. During teaching practice, trainee teachers are exposed to real school and classroom situation in order to help them develop teaching skills. Teaching practice is a period during which trainee teachers put into practice the various learning experiences they have acquired in the classroom and the theories they learnt into real life situation. Teaching practice is aimed at providing opportunities for student teachers to integrate theory and practice (Kiggundu 2007:27). The objectives of teaching practice are:

- To provide prospective teachers with the opportunity to establish an appropriate teacher/pupils relationship

- To provide an opportunity to put theory into practice and develop deeper understanding of educational principles and their applications for learning

- To provide the future teacher with experience in school to overcome the problem of discipline and enable him/her develop method of control

- To provide student teachers with the opportunity to have teaching evaluation and to gain from constructive criticism

- To provide an opportunity for evaluating the student potential as a teacher and suitability for the teaching profession

- To develop personal relationship with other administrators, teachers, parents and students

- To enable the student teacher to effectively plan and prepare lessons

- To develop desirable professional interest, attitude and ideas relative to the teaching profession

- To enable the student teacher acquire desirable characteristics/traits of a teacher and to develop appropriate behavior

- To develop skills in the use of fundamental procedures, techniques and methods of teaching

- To provide an opportunity for self evaluation and to discover ones strength and weakness (Akbas, 2002).

\subsection{Statement of the Problem}

There have been controversies over the attitude of student teachers towards teaching practice and the effectiveness of the teaching practice programme in Nigeria. Many education stakeholders in Nigeria believe that the poor performance of students in external examinations like West African Examination Council (WAEC), National Examination Council (NECO) and University Tertiary Matriculation Examination (UTME) is linked with teachers' ineffectiveness among other variables. The general believe by many Nigerians is that students are not interested in teaching profession. Though literature is replete on teaching practice in Nigeria, there are limited empirical studies on teaching practice in Delta State University, Abraka..

\subsection{Purpose of the Study}

This study focused on assessment of students' attitude and perception of teaching practice in Delta State University, Abraka. Specifically, the study intentions are:

1. To ascertain the general assessment of student teachers' attitude towards teaching practice by teachers and school heads of cooperating schools.

2. To find out the perception of student teachers of their relationship with mentors during teaching practice.

3. To find out the perception of student teachers regarding the supervision provided by their lecturers during teaching practice.

\subsection{Research Questions}

The study provides answers to the following questions:

1. How do school heads and teachers assess the attitude of student teachers towards teaching practice? 
2. How do student teachers perceive their relationship with mentors during teaching practice?

3. How do student teachers perceive the supervision provided by their lecturers during teaching practice?

\subsection{Hypothesis}

Two hypotheses were formulated and tested in this study as follows:

1. There is no significant difference between 300 level and 400 level student teachers in their attitude of towards teaching practice.

2. There is no significant difference between urban and rural school student teachers in perception of supervision by lecturers during teaching practice.

\subsection{Theoretical Underpinnings}

This study is hinged on situated learning theory which is relevant in explaining teaching practice. The situated learning theory propounded by (Lave and Wenger, 1991). In teaching practice the roles of the master teachers (mentors) and the apprentice (student teachers) in a practical or situated learning is based on two principles as follows. Learning takes place as a function of the context, culture and activity in which it occurs. This theory views learning as a process that occurs in a participatory social context. The participants are the master teachers while the apprentice learners are the student teachers. Learners acquire the knowledge, skills, values and other attributes they need to perform in the classroom by engaging in the school situation. Thus, they apply the abstract knowledge they acquired in their institutions of study to real life situations during teaching practice. Two concepts are relevant for situated learning these are "community of practice" and "legitimate peripheral participation". Learners identify with the practices appropriate with a specific community. Three elements define a community of practice namely mutual engagement of participants in action, negotiation of a joint enterprise and development of a shared repertoire (Lave and Wenger, 1991; Petro, 2013). Learners are legitimate peripheral participants in the practices of the teaching community during their practical teaching under the guidance of experienced teachers as mentors. Learning is a social process where identity, membership and inter-personal relationships are significant (Lave and Wenger, 1991; Beck and Kosnick, 2002; Petro, 2013).

\subsection{Literature Review}

Teaching practice is predicated on effective teaching which has been conceptualized by many scholars. The characteristics of effective teaching have been identified as teachers having knowledge of the subject, enthusiasm for teaching and for the subject and sensitivity to and concern for progress (Feldman, 1988; Ijeh, 2013). Young and Straw (1999) sees effective teaching as sensitivity to and concern with class level and progress, teacher preparation and organization of the course and teacher stimulation of interest in the course and its subject matter. Middle States Association for Colleges and Schools (1996) defined effective teaching as one that produces results in terms of the cognitive and affective development of the students. Effective teaching is the teaching that results in the attainment of predetermined goals and objectives. High quality teaching requires professional knowledge. Teacher content knowledge is imperative to the improvement of teaching and learning. Student teachers need to be properly groomed so that they can develop skills and attitudes needed for good teaching. Research has shown that good teaching can promote student growth and development (Marais and Meier, 2004; Feldman, 1989; Murray, 1990). The works of Lavy (2011) and Schwerd and Wuppermann (2011) suggest that what makes an effective teacher is focused on teaching practices and what teachers actually do in the classroom. In addition, McCormick (1996) identified three features of excellent teacher as:

- Having passion in their lives and a deep regard for their students

- They lead challenging and demanding lives that sets high standards and inspire their changes

- They are always fully engaged with mastery of life, with hearts and minds full of wonder and are open to new things and understanding new realities.

An excellent teacher should be able to make lesson interesting to students, provide diversified learning experiences and actively engage students in their learning. Study by Russel and Munby (1992) indicates that learning to translate one's knowledge of a subject area into subject content is one of the important and difficult things which student teachers have to know. Additionally, Newman (1996) and Zbikowski (1990) noted that teaching practice should be implemented in such a way that it provides student teachers with the opportunity for a reflective approach towards teaching. In their opinion, the development of classroom skills in student teachers has to include:

- Work with others as a team 
- See the perspectives of others towards teaching

- Communicate and exchange ideas

- Observe learners progress using a variety of methods

- Analyze and evaluate data collected in order to draw informed conclusions on the effectiveness of the teaching methods employed and engage in self assessment

- Develop the ability to criticize the existing state of affairs regarding teaching and learning from a moral, social and political point of view.

A student teacher by consistently reflecting on what he/she is doing, develop his/her mastery of the theory and practice of teaching and learning (Letho, 2001). This development is evidenced in the student teacher's way of planning his/her lesson, conducting teaching and learning activities, taking records of what is observed in his/her teaching and the reactions elicited from the learners. According to Zbikowski, (1990), the reflective attitude of a teacher is identified by a way of thinking about teaching and learning that involves making and taking responsibility for national and ethical choices. Teachers abilities such as seeing the perspectives of others, developing alternative explanation for observed events, taking responsibility for students' learning, giving them equal access and caring about them are ethical commitment which go together with reflective teaching (Letho, 2001). Colton and Sparks-Langer (1993) identified other distinguishing attributes of reflective teachers as efficacy, flexibility, social responsibility and consciousness. They defined efficacy as a teacher's belief that he/she has the ability to influence learners and school. They argued that without the quality of efficacy, teacher will not be motivated to examine their own practice and that efficacy enables a teacher to experiment and take risk.

Supervision of student teachers during teaching practice is aimed at ensuring that the broad aim of teaching practice is effectively achieved. The complexity of the problems of supervision requires experienced experts in order to establish the link between theory and practice (Mifsud, 1996). He emphasized that presenting lessons, administration, liaising with parents, teaching students with special needs and the socially deprived are not easily handled by novices. It becomes imperative for opportunities to be provided for student teachers in their practicing schools to obtain experience in a guided manner. According to Stones (1984), supervisors should ensure that in their helping function, they see student teachers develop skills in diagnosing their own performance so that they improve themselves further even after university education from their various institutions. Booth and Tibbs (1990) suggested two broad approaches towards supervision as clinical and counseling. Both approaches are aimed at improving students' teaching. Accordingly, supervisor becomes the clinician who has the recipe which will solve student teachers problems. Using the counseling approach, the supervisor remains muted and allows the student teachers to explore and articulate teaching styles. The supervisor's role is to provide encouragement to the student teacher so that he/her can bring up a detailed explanation of the pedagogy underpinning the lesson. From another perspective, Colton and Sparks-Langer (1993) identified cognitive coaching which requires supervisors to ask mediating questions that could encourage student teachers to delve into professional mental representations and values to explain why they acted the way they did and why the learners reacted the manner which was observed. Supervisors have to lead the student teachers in stages that are novice and advanced so that they can develop and become competent, proficient towards being experts as more experience is attained (Eisenhard, Belm and Romagnano, 1991). Hoover et al (1988) suggested that the standards for student teachers performance and progress be communicated among the supervisory team and students. This requires a definition of the expected behaviours and progress towards demonstration of mastery of those behaviours. Supervisors have to disclose the expected behaviours to the students before the commencement of the teaching practice programme.

In terms of relationship with mentors during teaching practice, Holloway (2001) and Maphosa et al (2007) maintained that a mentor is required to guide and lead the student teacher all the way, advising on short comings, appraising on strength and encouraging until the student teacher is able to present lesson effectively. Maphosa et al (2007) noted that mentors should be constantly empowered through workshops to enable them to be able to work effectively in leading and guiding student teachers. This suggestion implies that mentors need additional training in order for them to be effective in mentoring student teachers. Study by Kiggundu 2007:28) suggests that mentor and/or supervisor have considerable influence on the performance of the student teachers during teaching practice. Supervisors have the role of guiding, advising and helping the student teachers in the acquisition of the intended teaching skills (Komba and Kira, 2013). Ralph cited in Marais and Meiser (2004:22) described mentors as exploitative imposing exorbitant demands on student teachers in terms of work load. Such mentors exhibit unethical behaviour by abandoning their lessons to student teachers. Marais and Meiser (2004:230) found that student teachers were confused and lacked insight into the relationship between the theory they were taught by institutions and 
teaching practice. They added that student teachers were unable to relate what they had learnt to the teaching practice they encountered at schools. Some were disillusioned about workloads-marking, checking, assessing learners' work and lesson preparation (Beck and Kosnik, 2002:94-95).

Most of the studies reviewed above were conducted in foreign countries. In Nigeria, there is limited study on teaching practice. A study by Nwanekezi, Okoli and Mezieobi (2011) focused on the attitude of student teachers towards teaching practice in the University of Port Harcourt and found that student teachers were diligent to duty, resourceful, ready to take instruction and prompt to school. Nakpodia's (2011) work on teaching practice was a review. This present study provided empirical evidence on student teachers attitude and their perception of teaching practice in Delta State University Abraka, Nigeria.

\section{The Research Method and Procedure}

\subsection{Research Design}

This survey research adopted ex-post facto design. It made use of interview and questionnaire as instruments for data collection.

\subsection{Population of the Study}

The population of the study comprised all the 300 and 400 level students of the faculty of education Delta State University Abraka and their lecturers. As well as teachers and school heads of cooperating schools during the 2012/2013 academic year.

\subsection{Sample and Sampling Technique}

A sample of 200 student teachers made up of (equal number of 300 level and 400 level) was selected via the random sampling technique. 40 teachers of the cooperating schools (mentors) and 40 school heads selected through the stratified sampling technique from primary and secondary schools in urban and rural locations of Delta State, Nigeria where the student teachers had their teaching practice exercise. The overall sample size is 280 .

\subsection{Instrument for Data Collection}

Data for this study consists of both primary and secondary data. The primary source of data collection was the interview. The interview was considered appropriate because through the use of interview, the respondents feel relaxed and were able to express themselves about the phenomenon being investigated. The interview questions were later transmitted into questionnaire for ease of quantitative analysis of data. The questionnaire comprised three parts. The first part contained demographic variable of respondents eliciting information pertaining to their sex, status, school location and school type. The second part contained eight items meant for teachers and school heads of cooperating schools to assess the attitude of student teachers towards teaching practice. It was entitled "School Heads and Teachers Assessment of Student Teachers Attitude towards Teaching Practice Questionnaire (SHTASTATPQ". The third part contained thirteen items entitled "Student Teachers' Perception of Mentors and Supervision Questionnaire (STPMSQ)" meant to answer research questions 2-3.

\subsection{Method of Data Analysis}

Data for this study were analyzed through the use descriptive statistics such as percent, mean and standard deviation to answer the research questions and inferential statistics of t-test to test the hypotheses. The level of significance was established at 0.05 . For the research questions, the cut-off point of 2.50, the mid-point of the score was used in making decision as to whether to agree with the item or to disagree with the item. Consequently, items having mean score from 2.50 and above were regarded as agreed while items with mean score below 2.50 were regarded as disagreed.

\section{Results}

The results of data analysis are presented in tables below: 
Table 1. Attitude of Student Teachers towards Teaching Practice As Assessed By School Heads and Teachers

\begin{tabular}{lllllll}
\hline S/N & Items & 300 level & \multicolumn{2}{c}{ 400 level } & \multirow{2}{*}{ Remark } \\
\cline { 3 - 5 } & & Mean & SD & Mean & SD & \\
\hline 1 & They were always punctual to school & 3,35 & 0.90 & 3.40 & 0.66 & Positive \\
2 & Student teachers were interested in the TP exercise & 3,60 & 0.42 & 3.72 & 0.61 & Positive \\
3 & They were regular at school & 2.82 & 0.35 & 3.00 & 0.45 & Positive \\
4 & They showed concern for their students & 3.40 & 0.72 & 3.15 & 0.93 & Positive \\
5 & They participated in general school administration & 2.40 & 1.02 & 2.22 & 1.11 & Negative \\
6 & They readily accepted other responsibilities & 2.16 & 0.79 & 2.40 & 0.93 & Negative \\
7 & They prepared their lesson notes daily & 2.70 & 0.66 & 3.35 & 0.87 & Positive \\
8 & They were regular in class attendance & 2.86 & 0.88 & 3.60 & 0.40 & Positive \\
WM & & 2.91 & 0.68 & 3.10 & 0.67 & Positive \\
\hline
\end{tabular}

The data in table 1 indicates that the mean value for all the items except items 5 and 6 for both the 300 level and 400 level student teachers exceeded the mid-point of 2.50. In addition, the Weighted Mean (WM) scores of 2.91 and 3.10 for the two levels clearly showed that student teachers have positive attitude towards teaching practice. Although, they did not participate in general school administration and they did not readily accept other responsibilities.

Table 2. Student Teachers Views on Relationship with Their Mentors during Teaching Practice

\begin{tabular}{llclll}
\hline S/N & Items & Score & \% Agree & $\begin{array}{l}\text { \% } \\
\text { Disagree }\end{array}$ & Remark \\
\hline 1 & My mentor was supportive & 680 & 86 & 14 & Agreed \\
2 & My mentor encouraged me & 734 & 93 & 07 & Agreed \\
3 & My mentor provided enough guidance and direction & 744 & 94 & 06 & Agreed \\
4 & My mentor over worked me & 384 & 39 & 61 & Disagreed \\
5 & My mentor abandoned the class to me & 346 & 44 & 56 & Disagreed \\
6 & My mentor supervised me closely & 588 & 75 & 25 & Agreed \\
7 & My mentor was very helpful & 640 & 81 & 19 & Agreed \\
8 & I had a cordial relationship with my mentor & 762 & 97 & 03 & Agreed \\
\hline
\end{tabular}

The data in table 2 shows that the mean score for all the items except items 4 and 5 exceeded 2.50 the cut-off point. Generally, the student teachers had a good relationship with their mentors. Student teachers were not over worked by their mentors neither did their mentors abandoned their class to them.

Table 3. Student Teachers Perceptions on the Supervision by Their Lecturers

\begin{tabular}{llllll}
\hline S/N & Items & \multicolumn{2}{l}{ Urban schools } & \multicolumn{2}{l}{ Rural schools } \\
\cline { 3 - 6 } & & Mean & SD & Mean & SD \\
\hline 1 & I am satisfied by the assessment procedure of my supervisor & 3.00 & 0.92 & 2.40 & 0.66 \\
2 & My supervisor provided enough feedback to me & 2.76 & 0.64 & $2 . .73$ & 0.70 \\
3 & My supervisor discussed my strength and weakness with me & 2.82 & 0.35 & 2.60 & 0.45 \\
4 & My supervisor provided an opportunity for reflective teaching & 2.40 & 0.66 & 2.30 & 1.21 \\
5 & The assessment by my supervisor is encouraging & 3.04 & 0.46 & $2 . .28$ & 1.12 \\
\hline
\end{tabular}

From the data in table 3 , urban student teachers $(X=3.00)$ were satisfied by the supervision while rural student teachers $(X=2.40)$ were not satisfied. Both urban and rural school student teachers $(2.67$ and 2.73 respectively $)$ expressed that their supervisors provided enough feedback. Similarly, both urban $(X=2.40)$ and rural $(X=2.30)$ school student teachers were not given opportunity to reflect on their teaching. Both urban $(\mathrm{X}=2.82)$ and rural $(X=2.60)$ school student teachers are of the opinion that their supervisors discussed the strength and weakness of their teaching with them. Urban school student teachers $(X=3.04)$ saw the supervision by lecturers as encouraging while rural school student teachers $(X=2.28)$ said the supervision was not encouraging. 
Table 4. T-Test Showing Attitude of Student Teachers towards Teaching Practice

\begin{tabular}{llllllll}
\hline Groups & N & X & SD & DF & t-cal & t-crit & Decision \\
\hline 300 level & 97 & 23.82 & 5.49 & 194 & 1.353 & 1.96 & Not \\
400 level & 99 & 25.34 & 5.35 & & & & Significant \\
\hline
\end{tabular}

From table 4, the t-calculated value of 1.353 is less than the t-critical value of 1.96 at 0.05 level of significance. Hypothesis one is therefore not acceptable. Implying that 300 and 400 level student teachers did not differ significantly in their attitude towards teaching practice.

Table 5. T-Test of Urban and Rural School Student Teachers Perception of Supervision by Lecturers

\begin{tabular}{llllllll}
\hline Groups & N & $\mathbf{X}$ & SD & DF & t-cal & t-crit & Decision \\
\hline Urban & 136 & 14.02 & 3.03 & 194 & 3.231 & 1.96 & Significant \\
Rural & 60 & 12.31 & 4.13 & & & & \\
\hline
\end{tabular}

From table 5, the t-calculated value of 3.231 is greater than the t-critical value of 1.96 at 0.05 level of significance. Hypothesis one is therefore retained. Hence urban and rural school student teachers differed significantly in their perception of supervision by their lecturers during teaching practice.

\section{Discussion of Findings}

\subsection{Findings on Attitude of Student Teachers towards Teaching Practice}

The findings of the study on the attitude of student teachers towards teaching practice as assessed by mentors and school heads showed that they were always punctual at school, they were interested in the teaching practice programme, they were regular at school, they showed concern for their students, they did not participate in general school administration, they did not readily accepted other responsibilities, they prepared their lesson notes daily and were regular in school attendance. The weighted mean scores of 2.91 and 3.08 suggested that student teachers have a positive attitude towards teaching practice. This finding is supported by Nwanekezi, Okoli and Mezieobi (2011) and Farauta and Amuche (2013) their findings revealed that student teachers of the University of Port Harcourt and Nasarawa State University, Keffi respectively, have positive attitude towards teaching practice in areas such as regular attendance at school, writing lesson notes, punctuality at school and teaching ability. In addition, the finding has the support of Alkhan and Erdem (2010). Their finding showed that student teachers who received teaching application in educational technologies had positive attitude to their teaching practice. However, the fact that student teachers did not readily accept other responsibilities and did not participate in general school administration is not encouraging.

\subsection{Findings on Relationship of Student Teachers with Their Mentors during Teaching Practice}

The findings showed that $86 \%$ of student teachers said their mentors were supportive, A very significant proportion (93\%) and (94\%) said mentors were encouraging and provided enough guidance and direction respectively, Only $39 \%$ of student teachers felt overworked by their mentors, $44 \%$ of student teachers said their mentors abandoned the teaching to them. Majority of the student teachers (95\%) are of the opinion that mentors provided close supervision. A very significant proportion ( $81 \%$ ) of the student teachers said mentors were very helpful and majority of them (97\%) said that they had a cordial relationship with their mentors. A student teacher responded to the interview thus "my first experience in my 300 level was so dreadful but with my mentors encouragement and corrections, I kept going as I learnt a lot from her and soon became confident in my teaching". In addition, another student teacher said "my mentor made my task of teaching more interesting, enjoyable, better organized and effective." These expressions suggest that student teachers learnt better understanding of concepts and contents in their subject areas from the corrections of their mentors which is typical of the theory of teaching is learning. This finding lend credence with Kiggundu (2007) who found that student teachers had good relationship with their mentors which impacted positively on their performance during teaching practice.

\subsection{Findings on Student Teachers Perception of Supervision by Lecturers in Urban and Rural Schools}

The findings based on the supervision provided by lecturers in urban and rural schools indicated mixed feelings from the two groups. While urban school student teachers felt satisfied by the supervision provided by lecturers, rural school teachers expressed not satisfied. Even the interview report, the student teachers who said they were not supervised was all from rural schools. A particular student teacher who served in a rural school in Edo state 
expressed thus "I was not supervised at all, I felt frustrated". Another student teacher who served in a rural school in Delta North said "I went to the university to inform the teaching practice coordinator during the fifth week yet I was not supervised till the last day, I felt more frustrated". That rural school student teachers are not supervised by lecturers during teaching practice is not good for best practice in teaching. Supervisors have the role of guiding, advising and helping the student teachers in the acquisition of the intended teaching skills (Komba and Kira, 2013). But when student teachers are not supervised as indicated by the findings of this study in rural schools, the acquisition of teaching skills by trainee teachers may not be effective. Oslaitan and Agusiobo (1981) proved that giving student teachers more field experience that is supervised gives them an opportunity to develop healthy professional attitudes towards members of the teaching profession and pupils, chances to become skilled in using instructional materials to communicate with pupils for purposes of sharing meaning and chances to identify their strength and weaknesses in the spectrum of competencies associated with effective teaching. Student teachers need their supervisors' feedback and corrections in order for them to become effective teachers.

Regarding provision of feedback by supervisors, both urban and rural school student teachers said they were provided enough feedback. Both urban and rural school students teachers were not provided opportunity for reflective teaching. Interview report of a student teacher expressed "my supervisor rushed me, within fifteen minutes, he asked me to round up and went to another classroom" Urban school teachers $(X=3.04)$ said that the assessment by their supervisors (lecturers) were encouraging while rural school student teachers $(X=2.28)$ expressed discouraged with the assessment. From this findings, it can be said that the geographical location of student teachers affect their supervision. The result of this study showed that student teachers were not given opportunity for reflective teaching by their supervisors. This is not good enough for best practice in teaching. Studies have shown that the ability to reflect is an important attribute of an effective teacher (Borko, Michalee, Timmons and Siddle, 1997, Posner, 1996). A student teacher by consistently reflecting on what he/she is doing, develop his/her mastery of the theory and practice of teaching and learning (Letho, 2001). But when trainee teachers are not given opportunity for reflective teaching, the development of teaching skills could be hampered.

Findings based on the hypotheses showed that for hypothesis one, 300 and 400 level student teachers did not differ significantly in their attitude towards teaching practice. But for hypothesis two, urban and rural school student teachers differed significantly in their perception of supervision provided by their lecturers during teaching practice.

\section{Conclusion}

This study examined teaching practice among undergraduates of Delta State University Abraka, Nigeria. The findings revealed that student teachers have positive attitudes towards teaching practice. The findings further showed that student teachers had good and cordial relationship with their mentors in schools where the programme took place. The findings further indicated that student teachers mostly those in rural schools were not satisfied with their lecturers' supervision as some student teachers was not supervised.

\section{Recommendations}

The following have been recommended based on the findings of the study:

1. Lecturers should ensure that they visit student teachers in both urban and rural schools during teaching practice and supervise them.

2. More orientation should be provided by the institution for student teachers on classroom management and control.

3. The university should ensure that student teachers are posted to schools where access roads are available.

4. Student teachers should be made to know that participation in general school administration is among the duties expected of them during teaching practice.

\section{References}

Akbas, R. A. (2002). A study of practice teaching of prospective secondary school teachers and development of practice teaching model. Unpublished doctoral thesis, University of Agriculture Rawalpindi.

Alkhan, F., \& Erdem, E. (2010). The attitude of student teachers towards educational technologies according to their status of receiving teaching application lessons. Procedia Social and Behavioural Sciences, 2(2), 2523-2527.

Beck \& Kosnik. (2002). Student teachers perception of the components of a good practicum placement. Teacher 
Education Quarterly, 29(2), 81-98.

Booth, T., \& Tibbs, P. (1990). Enhancing cross-cultural and professional through schools. A Paper presented at the Annual conference of New Zealand Association of Educational Researchers, Auckland.

Carter, D. S. G. (2006). Evaluating the reflective practice of preservice teachers in Catholic secondary schools. Asian Pacific Journal of Teacher Education, 25(2), 159-171. http://dx.doi.org/10.1080/1359866970250205

Collins, A., Brown, J. S., \& Holum, A. (1991). Cognitive apprenternship: Making thinking visible. American Educator, 15(3), 38-46.

Colton, A. B. (1993). A conceptual framework to guide the development of teacher reflection and decision making. Journal of Teacher Education, 44(1), 45-54.

Cruiksbank, D.R., \& Amaline, W. D. (1986). Field experience in teacher education. Journal of Teacher Education, $35,34-45$.

Diamond, C. T. P. (1991). Teacher education as experience formation. London: Open University Press.

Eisenhard, M., Belm, L., \& Romagnono, L. (1991). Learning to teach developing expertise or rite of passage? Journal of Education for Teaching, 11, 52-56.

Ekundayo, H. T. et al. (2014). Teaching practice exercise for education students in Universities: Challenges and the way forward. Mediterranean Journal of Social Sciences, 5(9), 486-492. http://dx.doi.org/10.5901/mjss2014.v5v9p486

Fafunwa, B. (1974). The history of education in Nigeria. Ibadan: Macmillan Publishers.

Farauta, K. G., \& Amuche, C. I. (2013). Assessment of attitude of education students towards teaching practice in Nasarawa State University, Keffi, Nigeria. Journal of Education and Practice, 4(13), 181-183.

Feldman, K. (1988). Effective college teaching from the students and faculty's view: Match or mismatched priorities? Research in Higher Education, 28(4), 291-344.

FGN (2004). National policy on education. Abuja: NERDC.

Heeralal, P. J., \& Bayaga, A. (2011). Pre-service teachers' experiences of teaching practice: case of South African University. Journal of Social Sciences, 28(2), 99-105

Holloway, W., O'Shea, L., \& Carroll, R. (1988). The supervisor intern-relationship and effective interpersonal communication skills. Journal of Teacher Education, 39, 22-27.

Husband, C. (1994). Integrating theory and practice in teacher education: The UEA model of action research based teacher education. In B. Field and T. Field (eds.), Teachers as mentors: A practical guide. London: Falmer.

Ijeh, S. B. (2013). Analysis of Davis's classroom practices in search of teacher-demonstrated pedagogical content knowledge in statistics teaching. Mediterranean Journal of Social Sciences, 4(3), 735-742.

Jekayinfa, A. A. et al. (2012). Lecturer's assessment of teaching practice exercise in Nigerian universities. Journal of Education and Practice, 3(4), 79-86.

Kiggundu, E. (2007). Teaching practice in the greater Vaal triangle area: The student teacher's experience. Journal of College Teaching and Learning, 46, 25-36.

Kiggundu, E., \& Nayimuli, S. (2009). Teaching practice a make or break phase for student teachers. South African Journal of Higher Education, 29, 345-358.

Komba, S. C., \& Kira, E. S. (2013). The effectiveness of teaching practice in improving student teachers' teaching skills in Tanzania. Journal of Education and Practice, 4(1), 157-163.

Lave, J., \& Wenger, E. (1991). Situated learning: Legitimate peripheral participation. Cambridge: Cambridge University Press.

Lavy, V. (2011). What makes an effective teacher? Quasi-Experimental evidence. NBER Working Paper 16885.

Lawal, B.O. (2012). Analysis of parents, teachers and students perception of teaching profession in South-West Nigeria. Asian Journal of Social Sciences, 8(1), 119-124.

Letho, T. S. (2009). An effective student-teaching practice programme. Retrieved February 10, 2013 from www.spectrumlibrary.concordia.ca/1464/1/MQ82665.pdf

Manka, V. M., \& Lee, W. (2002). Reconsidering the novice/expert dichotomy in the K-12 mentor-mentee 
relationship. Journal of In-service Education, 28(1), 23-34. http://dx.doi.org/10.1080/13674580200200169

Maphosa, C., Shumba, J., \& Shumba, A. (2007). Mentorship for student teaching practice in Zimbabwe; Are student teachers getting a raw deal? South African Journal of Higher Education, 21, 296-307.

Marais \& Meier. (2004). Hear our voices: Student teacher's experience during practice teaching. African Education Review, 1(2), 220-233.

McCorrick, P. (2006). There is no substitute for good teachers. US Catholic, 6(6), 101-112.

Middle States Association of Colleges and Universities (1996). Framework for outcomes assessment. Pennsylvania, Philadelphia: Commission on Higher Education

Mifsud, C. (1996). Preparation and competence in intending and beginning teachers in Malta. Journal of Teaching, 23, 281-291.

Mohammed, M. O. B., Gbenu, J. P., \& Lawal, R. O. (2014). Planning the teacher as in Loco parentis for an effective school system. Mediterranean Journal of Social Sciences, 5(16), 318-321. http://dx.doi.org/10.5901/mjss.2014v5n16p318.

Mudzielwana, P. N., \& Maphosa, C. (2014). Trainee teachers' experiences of being pbserved teaching while on teaching practice: A case of a rural-based University in South Africa. Mediterranean Journal of Social Sciences, 5(16), 393-402. http://dx.doi.org/5901/mjss.2014v5n16p393

Murray, H. G. (1991). Effective teaching behavior in the college classroom. In J. C. Smart (ed.), Higher Education: Handbook for Theory and research, VII. New York: Agathon Press.

Nakpodia, E. D. (2011). Teacher and the student Practice teaching programme in Nigerian educational system. International Journal of Educational Administration and Policy Studies, 2(3), 33-39.

Newman, J. S. (1996). Reflection on teacher education. Journal of Teaching, 22, 297.

Nwanekezi, A. U., Okoli, N. J., \& Mezieobi, S. A. (2011). Attitude of student teachers towards teaching practice in the university of Port Harcourt, Rivers State, Nigeria. Journal of Emerging Trends in Educational Research and Policy Studies, 2(1), 41-46.

Okemakinde, T., Adewuyi, J. O., \& Alabi, C. O. (2013). The place of teacher in national development in Nigeria. European Journal of Humanities and Social Sciences, 19(1), 964-980.

Olulobe, N. P. (2007). Teacher education, school effectiveness and improvement. Unpublished doctoral thesis, University of Helsinki, Finland.

Oluwatayo, J. A., \& Adebule, S. O. (2012). Assessment of teaching performance of student teachers on teaching practice. International Education Studies, 5(5), 109-115. http://dx.doi.org/10.5539/iesn5v5p109

Oslaitan, S. O., \& Agusiobo, N. O. (1981). Principles of practice teaching. New York: Wiley.

Petro, M. A. (2013). A Platform for partnership: Preparing student teachers for parent-teacher participation. Journal of Educational and Social Research, 3(7), 419-424. http://dx.doi.org/10.5901/jesr.2013.v3n7.419

Posner, G. J. (1996). Field experience: A guide to reflective teaching ( $4^{\text {th }}$ edition). White Plains, New York: Longman.

Schwerdt, G., \& Wuppermann, A. C. (2011). Is traditional teaching really all that bad? A within-Student between-Subject approach. Economics of Education Review, 30, 365-379.

Stones, E. (1984). Supervision in teacher education: A counseling and pedagogical approach. London: Methuen \& Co Ltd.

Ukeje, B. O. (1988). Education for the survival of the Nigerian nation. Inaugural lecture series 4, Port Harcourt: University of Port Harcourt Press.

Young, S., \& Straw, D. G. (1999). Profiles of effective college and teachers. Journal of Higher Education, 70(60), 670-686.

Zbikowski, J. (1990). Understanding the teaching perspectives of first year teachers. Journal of Teacher Education, 41, 28-29. 